\title{
Effects of Job Rotation Strategy on High Performance Workplace, in Lake Victoria North Water Services Board, Kenya
}

\author{
Benjamin Kipchumba Tarus ${ }^{1}$ \\ ${ }^{1}$ Department of Business and Management Sciences, University of Eldoret, Kenya \\ Correspondence: Benjamin Kipchumba Tarus, Department of Business and Management Sciences, University of \\ Eldoret, P.O. Box 1125, Eldoret, Kenya. E-mail: tarusbk@gmail.com
}

Received: June 30, 2014

Accepted: September 15, $2014 \quad$ Online Published: October 22, 2014

doi:10.5539/ijbm.v9n11p139

URL: http://dx.doi.org/10.5539/ijbm.v9n11p139

\begin{abstract}
The study investigates job rotation as a strategy of high performance workplace in Lake Victoria North Water Services Board in Kenya. High Performance Workplace is very critical to an organization as it determines its profitability and given the need to sustain competitive advantage and to improve organizational performance, a number of organizations have adopted job rotation as a strategy to sustain their existence in the industry. The study utilized explanatory survey design, stratified sampling and simple random sampling in obtaining the respondents. Structural equation model was used for model specification and hypotheses testing. The results of the SEM indicated that job rotation significantly predicted high performance workplace $(\beta=0.38, C R=5.938$, $\mathrm{p}<0.001)$ thereby supporting prior research. The study contributed to development of measurement of variables, factor Reliability coefficients and job rotation model. The findings further indicate that organizations can improve performance by enhancing job rotation strategy.
\end{abstract}

Keywords: high performance, job rotation, Kenya, workplace, lake victoria north water services board

\section{Introduction}

Organizations in the 21 st century face rapid changes in the external business environment that impact the operation of the internal environment (Blanchard, 2006). The demands made by customers, skilled workers, regulators, social activists and shareholders increase the pressure on firms to deliver excellent performance while satisfying the diverse needs of stakeholders (Watson, 2007; Schermerhorn, et al., 2004). An understanding of job rotation is necessary to decipher the needs of the individuals and groups within the organization in order to utilize maximize experience which translates to high performance workplace. High Performance Workplace strives to get the best in people as a means to achieve sustainable results. Leaders, who put people first when setting the organizational objectives, inspire their workforce to pursue high performance while meeting the expectations of all the stakeholders (McClelland \& Burnham, 2003).

Job rotation involves lateral transfers of employees between jobs in an organization. In this, Senge (1999) implies systematic movement of employees from one job to the other. The portfolio remains constant but employees performing them move from one portfolio to the other, (Champion et al., 1994). According to Metin et al. (1998) job rotation is important in two aspects namely; an employee who rotates without changing the portfolio accumulates experience more than the one who does not hence, it is an effective tool for career development. Consequently he/she accumulates experience in more departments hence; it is easier to train him to become a generalist.

Studies done by Ombogo (2006) indicated that water boards in Kenya continue to experience problems of customer dissatisfaction through; lack of quality water, delay in action for problems and complaints, unreliable water supply low morale of staff lack of customer focus, high water loses, insufficient revenues and low billing yet they have embraced job rotation. Cusumano and Selby (1995) posited that even after project postmortems are done and recommendation made, errors keep repeating themselves a problem attributed to implementation of lessons learned.

Job rotation in an organization contains three elements namely; individual learning, knowledge from outside resources and reciprocal action between employees and therefore it is regarded as an excellent catalyst of improving utility of outside learning resources. It is therefore, a strategy conducted by organizations to improve 
employee performance and productivity. Despite the fact that companies have adopted job rotation, there are still persistent complaints and therefore this study seeks to find the linkage between job rotation and high performance workplace.

\section{Literature Review}

\subsection{Theoretical Perspectives}

The concept of high performance workplace is informed by Parson's theory (1951). He theorized that the collective is composed of the social interactions of actors, objects and norms and is more than the sum of the actions and attitudes of individuals in the collective system. These systems of interactions emerge from multiple levels of analysis namely; individual, group, organization or societal. The theory of action proposes that performance and learning processes upsets the dynamic balance in a social system creating change. Change in a social system occurs through both learning process and performance process (Swhwandt, 1997). The theory concentrates on the systematic relationship between the actions of actors in the social system and their collective capacity to adapt to internal and external environments. Studies on job rotation and performance in Keshavarzi Banks of Gilan (2013) indicated that organizations obtain sustained competitive advantage depending on personnel productivity, learning systems development and developing employee intellectual asset. According to Xie, (1995) he posited that developing and improving skills is a requirement for organizational capabilities and coping with new developments and challenges. He further argued that job rotation is a cure of stress thus improves on job and occupational status of an employee.

The theory proposed that social action consists of an actor, a situation, symbols, norms and values. A social actor is referred to an individual or a group or organization. The theory is based on voluntarism where an actor makes choices among a variety of values and provides possible actions through a creative process (Ritzer, 1992). Focus of Parsons theory is on social actions where four functional prerequisites of a system needs are namely; 1 . Adaptation: These are actions that create and sustain relationships with internal and external environments. They also bring resources into the system in exchange for resources created. 2. Goal attainment; these are actions that set the goals of the system and aid in managing the required resources in order to achieve the goals. 3 . Integration; These actions coordinate the system. 4. Latency or pattern maintenance; these actions represent the organizations symbols and culture. This system of actions accumulates and distributes energy in the form of motivation (Rogers, 2003).

The functional prerequisites are generalized to all levels of analysis namely; individual, group, activity, network, organization and society as well as all other types of systems. The subsystems of action are interdependent and help to create a process of mutual exchange of energy and resources which in turn supports the total system of action (Schwandt, 1997). Parson described these exchanges as the media of interchange. The theory is relevant to the study because it recognizes learning organization and aids in meshing the organization as a unified purposeful system composed of interrelated parts to achieve high performance workplace.

Jaime (2000) posited that job rotation promotes psychological and physical health of employees through creating positive attitudes on employees, facilitating their health and increasing the variety of work through reduction of boredom to work, seeing things in a new perspective, decreasing in physically demanding portfolios and having self motivation towards their positions in organizations. Plowman (2010) confirms that when the strategy is implemented in line with the business goals and human resource strategies of the organization it aids in stimulating human mind through diversity of challenges. Studies by Ortega (1999) and Weichel et al. (2010) indicated job rotation could be used for development of knowledge and fusion both in breadth and depth and when this strategy takes effect those who have rotated are expected to master new knowledge and to integrate all facets of knowledge resources in the organization.

This paper was guided by one objective: To investigate the effect of job rotation as a strategy on high performance workplace and a null hypothesis: Ho1: There is no significant effect of job rotation on high performance workplace

\section{Research Methodology}

The study was undertaken in Lake Victoria North Water Services Board in Kenya. It utilized explanatory survey design because it minimizes bias and provides an opportunity for probability sampling which maximizes reliability of data collected. The target population for this study included all employees and management of Lake Victoria North Water Services Board as derived from the employment records. This number stood at 977 by the time of the study while the sample size was 276 representing $28.3 \%$ of the respondents. The study utilized stratified sampling technique to obtain employees on each department and lastly, simple random sampling 
technique was used to select employees on each department.

\subsection{Measurement of Variables}

The items to measure job rotation impacts on high performance workplace were developed by researcher (2014). A principal component factor analysis of each of the variables was undertaken Table 2. Kaiser-Meyer-Olkin measure of sampling adequacy test $(0.806)$ and the Bartlett's test of sphericity $(p<0.001)$ was realized. Reliability for the eleven items measuring job rotation was 0.660 on the basis of Cronbach's Alpha reliability estimate, which falls in the recommended lower limit reliability estimate of 0.60 to 0.70 (Hair et al., 2006). The construct was categorized into two different sub-dimensions: human capital development and human capital transformation. For the purpose of this study, all the two sub-dimensions of job rotation were measured. Items that were used to measure each sub-dimension were summated, and summated scales were used to assess high performance workplace impact of job rotation. As shown in figure 3.1 below, six items were used to measure human capital and five items were utilized to measure human capital transformation. A five point Likert scale type; strongly disagree (SD) equals to one, disagree (D) equals to two, neither disagree nor agree equals to three (NDNA), agree equals to four and strongly agree (SA) equals to five was used to measure these items.

\section{Human capital development}

A1. I am satisfied that Job rotation has led employees to advanced learning;

A2. Since coming to this organization, I have developed positive attitude towards learning;

A3. I am confident that Job rotation has increased our efficiency in learning;

A 4.I am fully aware that Job rotations is a tool for career development;

A5. I have accumulated a lot of experience through job rotation;

A6. Job rotation has promoted communication between employees.

Human Capital Transformation

A7. I believe that Job rotation has improved my job stability;

A8. I am confident that job rotation policy has achieved effective results in my organization;

A9. I am confident that Job rotation has promoted health of employees in my organization;

A10. I am aware that job rotation as not achieved effective results in my organization;

A11. I am confident that job rotation does not create effective results.

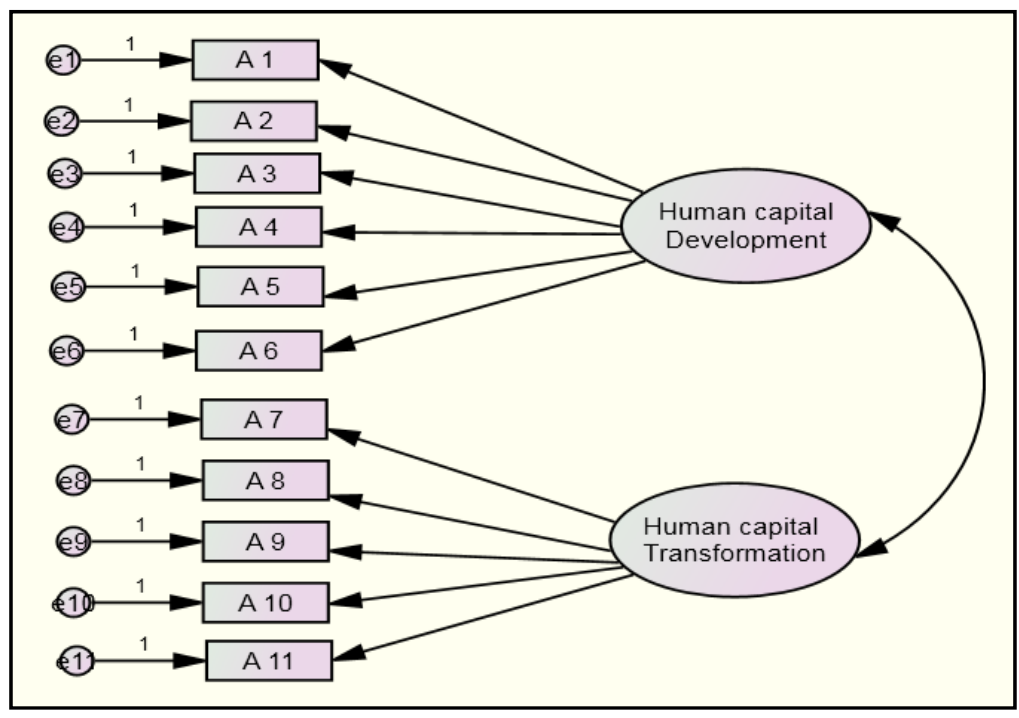

Figure 1. Hypothesized measurement model for job rotation

Source: Survey Data, (2014). 


\section{Results and Discussions}

\subsection{Perceived Job Rotation Strategy}

The respondents were asked to respond to eleven items reflecting on job rotation. As shown in Table 1 the respondents tended to agree that job rotation has led employees to advance learning $(\mathrm{M}=3.73), \mathrm{SD}=1.062$. The skewness and kurtosis values were within the acceptable limits of normality $(-2$ to +2$)$. This confirms that normality requirements were met for the data on this scale.

On the overall, the employees perceive job rotation positively (the mean response to most items points to agreement). The highest mean scores attained were associated with job rotation as a tool for career development $($ mean $=3.89)$, development of positive attitude towards learning (mean $=3.86)$ and accumulation of experience $($ mean $=3.83)$. These findings imply that employees regard job rotation highly in view of their career and experience. This is then likely to impact positively on high performance work place.

With respect to the mean response scores, the results show that the respondents appeared to agree that job rotation has led to employees to advance learning $(\mathrm{M}=3.73, \mathrm{SD}=1.062)$; that they have developed positive attitudes towards learning $(\mathrm{M}=3.86, \mathrm{SD}=0.978)$, that they were aware that job rotation is a tool for career development $(\mathrm{M}=3.89, \mathrm{SD}=0.959)$, that they have accumulated a lot of experience through job rotation $(\mathrm{M}=$ $3.83, \mathrm{SD}=1.012)$, that job rotation has promoted communication among employees $(\mathrm{M}=3.76,0.921)$, and that they were confident that job rotation had achieved effective results in their organization $(\mathrm{M}=3.60, \mathrm{SD}=0.988)$. They were however non-committal on whether job rotation has improved their job stability $(\mathrm{M}=3.46, \mathrm{SD}=$ $1.166)$ and whether job rotation has promoted health of employees $(\mathrm{M}=3.37, \mathrm{SD}=1.107)$.

Table 1. Perceived job rotation strategy

\begin{tabular}{|c|c|c|c|c|c|c|}
\hline & Mean & $\begin{array}{l}\text { Std } \\
\text { Deviation }\end{array}$ & $\begin{array}{l}\text { Skewnes } \\
(\mathrm{SE}=.159\end{array}$ & & Kurtosis & \\
\hline & Statistic & c Statistic & Statistic & Std. Error & Statistic & c Std Error \\
\hline A1.I am satisfied that job rotation has led to employees to advanced learning & 3.73 & 1.062 & -.935 & .159 & .579 & .316 \\
\hline $\begin{array}{l}\text { A2.Since coming to this organization, i have developed positive attitude towa } \\
\text { learning }\end{array}$ & $\mathrm{ds} 3.86$ & .978 & -.914 & .159 & .471 & .316 \\
\hline A3.I am confident that job rotation has increased our efficiency in learning & 3.58 & 1.069 & -.684 & .159 & -.086 & .316 \\
\hline A4.I am fully aware that job rotation is a tool for career development. & 3.89 & .959 & -.833 & .159 & .607 & .316 \\
\hline A5.I have accumulated a lot of experience through job rotation & 3.83 & 1.012 & -.815 & .159 & .292 & .316 \\
\hline A6.Job rotation has promoted communication between employees & 3.76 & .921 & -.699 & .159 & .311 & .316 \\
\hline A7.I believe job rotation has improved my job stability & 3.46 & 1.166 & -.570 & .159 & -.415 & .316 \\
\hline $\begin{array}{l}\text { A8.I am confident that job rotation has achieved effective results in } \\
\text { organization }\end{array}$ & y3.60 & .988 & -.671 & .159 & .203 & .316 \\
\hline $\begin{array}{l}\text { A9.Iam confident that job rotation has promoted health of employees in } \\
\text { organization }\end{array}$ & ny 3.37 & 1.107 & -.526 & .159 & -.308 & .316 \\
\hline $\begin{array}{l}\text { A10.Iam aware that job rotation has not achieved effective results in } \\
\text { organization }\end{array}$ & ny 2.20 & 1.208 & .862 & .160 & -.152 & .318 \\
\hline A11.I am aware that job rotation does not create effective results & 2.16 & 1.249 & .832 & .160 & -.434 & .318 \\
\hline
\end{tabular}

Source: Survey Data, (2014).

\subsection{Job Rotation Dimension}

Eleven items were proposed to measure job rotation. From principals component factor analysis, results of the Kaiser-Meyer-Olkin measure of sampling adequacy test $(0.806)$ and the Bartlett's test of sphericity $(\mathrm{p}<0.001)$ test of sphericity $(p<0.001)$ indicated that the data were acceptable for factor analysis (Table 2$)$. The principal components factor analysis extracted two factors explaining $50.5 \%$ of the total variance of the scale. All the factor loadings were greater than 0.6 and loaded on two factors namely; human capital development and human capital transformation. Reliability for the eleven items measuring job rotation was 0.660 on the basis of Cronbach's Alpha reliability estimate, which falls in the recommended lower limit reliability estimate of 0.60 to 0.70 (Hair et al., 2005). It was therefore concluded that job rotation could be measured by two factors, one of which would have 4 items (human capital development) and the other 2 items (human capital transformation). 
Table 2. Factor analysis on job rotation

\begin{tabular}{llcl}
\hline Construct and Scales & Loading & $\begin{array}{c}\text { Eigen values } \\
\text { Variance } \\
\text { explained }\end{array}$ & $\mathbf{3 6 . 4 \%}$ \\
\hline Job rotation & $.660^{*}$ & $\mathbf{4 . 0 0 7}$ & \\
Human capital development & & & \\
Accumulated experience & 0.709 & \\
Improved job stability & 0.673 & & \\
Achieved effective results in organization & 0.636 & $\mathbf{1 4 . 0 3 4 \%}$ \\
Promoted health of employees in organization & 0.729 & $\mathbf{1 . 5 4 4}$ & \\
Human capital transformation & & & \\
Not achieved effective results & 0.828 & & \\
Not created effective results & 0.864 & & \\
Kaiser-Meyer-Olkin MSA Bartletts Test of Sphericity & $\mathbf{0 . 8 0 6}$ & $\mathbf{0 . 0 0 0}$ & \\
\end{tabular}

Note. * Reliability coefficient (Cronbach's Alpha);

Source: Survey Data, (2014).

\subsection{Confirmatory Factor Analysis for Job Rotation}

The confirmatory measurement model to be tested postulated a priori that job rotation is a two-factor structure composed of Human Capital Development and Human Capital Transformation. Further examination of the model indicated that the two factors were correlated and that there were six observed variables. The results of the initial measurement model did not fit the data well. The chi-square statistic valued at 22.7 with 8 degrees of freedom was statistically significant at the 0.05 level, indicating a poor fit. The other fit statistics indicated that the model was not a bad fit $\left(\chi^{2} / \mathrm{df}=2.849, \mathrm{GFI}=0.972\right.$; AGFI $=0.927$; CFI $=0.951$; RMSEA=0.089). All the fit indices used other than the RMSEA were within the acceptable limits. The modification indices however suggested that a better fit could be achieved by modifying this measurement model. Figure 2 presents the hypothesized measurement model.

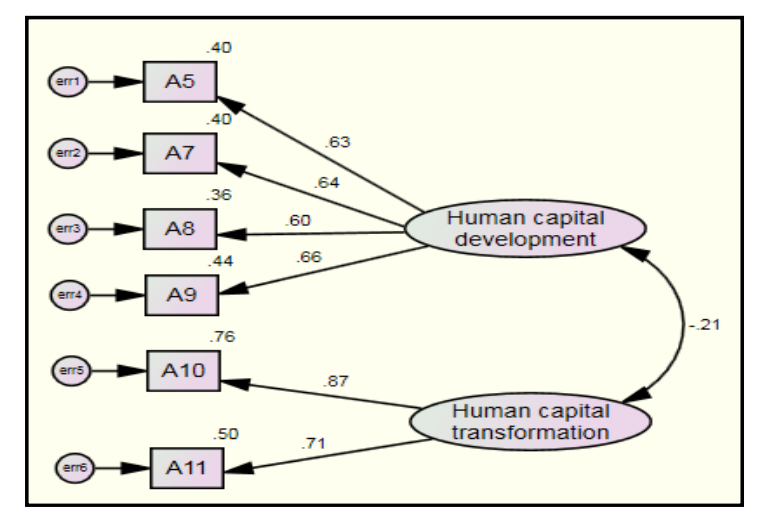

Figure 2. Proposed measurement model for job rotation

Source: Survey Data, (2014).

The modification model was developed by correlating the error terms of the items A5 and A8 under Human Capital Development. The results yielded a very good model fit. The chi-square statistic value of 2.746 with 6 degrees of freedom was not significant at $\mathrm{p}<0.05$. The other fit indices were also well within the acceptable limits indicating that the model was acceptable $\left(\chi^{2} / \mathrm{df}=0.458 ; \mathrm{GFI}=0.996 ; \mathrm{AGFI}=0.986 ; \mathrm{CFI}=1.000\right.$ and RMSEA $=0.000)$. Figure 3 presents the modified measurement model. 


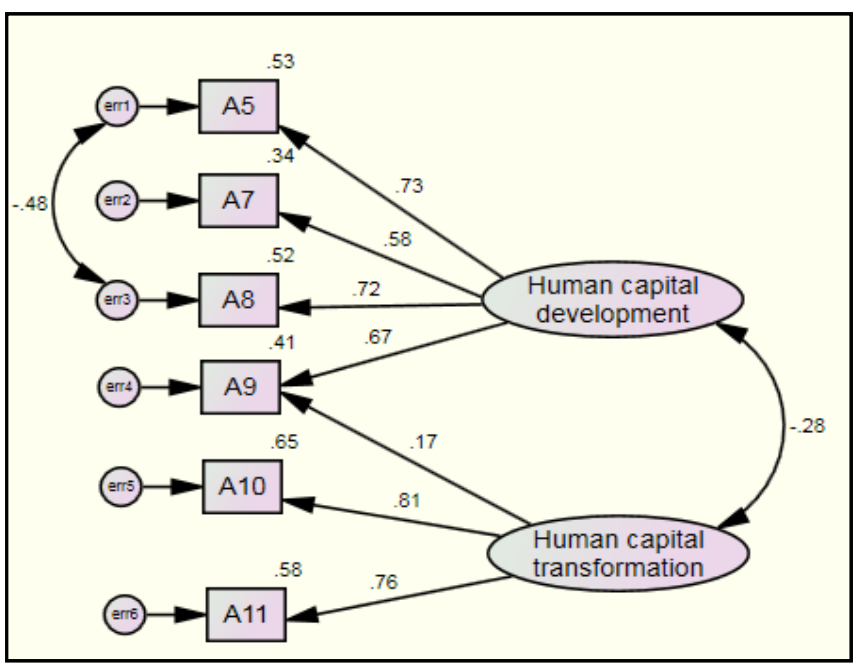

Figure 3. Modified measurement model for job rotation

Source: Survey Data, (2014).

Examining the standardized residual covariance displayed in Table 3 showed that no value exceeded the standardized value cut-off point of 2.58 . The highest value was 0.710 which confirms that the model was a good fit to the data. Table 4 presents the final results of confirmatory factor analysis of job rotation. The composite indicator reliability and variance extracted estimates were calculated using the formula recommended by Fornell and Larker (1981) i.e composite reliability $=\left(\sum \mathrm{Li}\right)^{2} /\left(\left(\sum \mathrm{Li}\right)^{2}+\sum \operatorname{var}\left(\mathrm{E}^{\mathrm{i}}\right)\right.$ and variance extracted $=\sum \mathrm{Li}^{2} / \sum \mathrm{Li}^{2}+$ $\sum \operatorname{var}(\mathrm{Ei})$. Where $\mathrm{Li}$ is the standardized loading, $\mathrm{Li} 2$ is the reliability of an indicator and $\mathrm{Ei}=\mathrm{I}-\mathrm{Li}^{2}$ is the error variance. As shown in Table 4.3 all of the observed variables in the modified model demonstrated factor loadings of 0.58 or greater and the variance extracted estimates were above 0.45 . This provides evidence of good validity. In addition, the reliability of the observed variables ranged from 0.34 to 0.65 while the composite reliabilities were above 0.7 indicating a good level of reliability.

Table 3. Standardized residual covariance (final job rotation model)

\begin{tabular}{lcccccc}
\hline & $\mathrm{A} 11$ & $\mathrm{~A}_{9}$ & $\mathrm{~A} 10$ & $\mathrm{~A} 7$ & $\mathrm{~A} 8$ & $\mathrm{~A} 5$ \\
\hline $\mathrm{A} 11$ & .000 & & & & & \\
$\mathrm{~A} 9$ & .148 & .000 & & & & \\
$\mathrm{~A} 10$ & .000 & -.116 & .000 & & & \\
$\mathrm{~A} 7$ & .710 & .163 & .165 & .000 & & \\
$\mathrm{~A} 8$ & -.450 & .190 & -.329 & -.426 & .000 & \\
$\mathrm{~A} 5$ & .365 & -.234 & .169 & .418 & .000 & .000 \\
\hline
\end{tabular}

Source: Survey Data, (2014).

Table 4. CFA for job rotation

\begin{tabular}{llll}
\hline Constructs and indicators & Standardized loading (Li) & Reliability $(\mathbf{L i})^{2}$ & Error variance (Ei) \\
\hline Human capital development & & $\mathbf{0 . 7 7 ^ { * }}$ & $\mathbf{0 . 4 5 * *}$ \\
$\begin{array}{l}\text { A5 I have accumulated a lot of experience through } \\
\text { job rotation. }\end{array}$ & 0.73 & 0.53 & 0.47 \\
$\begin{array}{l}\text { A7 I believe that job rotation has improved my job } \\
\text { stability }\end{array}$ & 0.58 & 0.34 & 0.66 \\
$\begin{array}{l}\text { A8. I am confident that job rotation policy has } \\
\text { achieved effective results in my organization }\end{array}$ & 0.72 & 0.52 & 0.48 \\
\hline
\end{tabular}




$\begin{aligned} & \text { A9. I am confident that job rotation has promoted } \\ & \text { health of employees in my organization }\end{aligned}$
$\begin{aligned} & 0.67 \\ & \text { Human Capital Transformation }\end{aligned}$
$\begin{aligned} & \text { A10. I am aware that job rotation has not achieved } \\ & \text { effective results in my organization }\end{aligned}$
$\begin{aligned} & \text { A11. I am confident that job rotation does not } 0.81 \\ & \text { create effective results }\end{aligned}$

Note. $*$ Composite reliability; ** Variance extracted estimate.

Source: Survey Data, (2014).

\section{Discussion of Findings}

It was hypothesized that employee job rotation had no significant effect on high performance workplace. The results of the SEM indicated that job rotation was a significant predictor of high performance workplace $(\beta=0.38$, $\mathrm{CR}=5.938, \mathrm{p}<0.001$ ). This indicated that enhanced job rotation was more likely to lead to high levels of high performance workplace. These findings are consistent with previous studies conducted by Metin et al., (1998), who observed that job rotation enabled an employee to accumulate experience both in his line of work and in a variety of fields thereby leading to improved high performance workplace. These views were also echoed by Jaime (2000) in positing that job rotation promotes psychological and physical health of employees through creating positive effects on employees, facilitating their health and increasing the variety of work through boredom to work, seeing things from different dimensions, and maintaining employee interest in the work.

Other researchers have added to the literature regarding the importance of job rotation with regards to capacity development. Plowman (2010) confirmed that when job rotations are implemented in line with the business goals and human resource strategies of the organization, it aids in stimulating the human mind through the diversity of challenges thereby bringing to the forefront, the minds creative instincts and taking both the individual employees and the organizational performance to a higher plane. Ortega (1999) on his part indicated that job rotation is a kind of a catalyst of assimilating knowledge from outside resources, while Weichel et al.,(2010), contended that job rotation is a reciprocity that results in fusion of knowledge and development of knowledge both in width and depth thereby establishing a substantial base for updating and creation of knowledge. The findings in this study suggest that job rotation as a learning organizational strategy can equally be applied by the Lake Victoria North Water Board to enhance a high performance workplace within the board.

\section{Conclusion}

The findings of this study showed that job rotation as a strategy had a significant effect on high performance workplace. This means that as organizations enhance job rotation, they are more likely to perform highly. Thus it is recommended that the management of water boards need to consider the strength of this relationship, and focus on maintaining high performance workplace derived from job rotation strategy.

These findings also suggest that water services boards in Kenya should know how employees perceive job rotation and how it affects their psychological empowerment. This is in bearing in mind that empowerment opportunities may be limited when employees perform routine, repetitive production or service jobs. There is more potential for meaningful work and self determination in jobs that have complex tasks and enriching job characteristics. If the employees in the water services boards always perceive job rotation positively, they may have control over several tasks making the jobs more intrinsically motivating. Employees' experience of intrinsic motivation would mean that the work they do generates the three psychological states of experienced meaningfulness of the work experienced responsibility for outcomes of work and knowledge of the actual results of work activities.

\subsection{Contributions of the Study}

The paper contributed to the theory, literature, development of measurements scales for job rotation and its model.

\subsection{Limitations of the Study}

The study was delimited to testing only the direct effect of job rotation strategy on high performance workplace and it was only undertaken in water board employees. Inclusion of stakeholders may help to better the relationship between job rotation strategy and high performance workplace. 


\subsection{Recommendations for Future Research}

The paper recommends that there is need to investigate water service consumers and other stakeholders in the water service industry.

\section{References}

Blanchard, S. (2006). The Leadership-Profit Chain. Escondido, California. The Ken Blanchard Companies.

Champion, M. A., Cheraskin, L. S., \& Michael, J. (1994). Career-Related Antecedents and Outcomes of Job Rotation. Academy of Management Journal, 37(6), 1518-1542. http://dx.doi.org/10.2307/256797

Cusumano, M. A., \& Selby, R. W. (1995). Microsoft Secrets: How the World's Most Powerful Software Company Creates Technology, Shapes Markets, And Manages People. New York, NY: The Free Press.

Fornell, C., \& Larcker, D. F. (1981). Structural Equation Models with Unobservable Variables and Measurement Error-Algebra and Statistics. Journal of Marketing Research, 18(3), 382-388. http://dx.doi.org/10.2307/3150980

Hair et al. (2006). Multivariate Data Analysis (6th ed.). New Jersey: Prentice Hall.

Hair, J., Anderson, R., Tatham, R., \& Black, W. (1998). Multivariate Data Analysis (5th ed.). London: Prentice-Hall International.

Jaime, O. (2000). Job Rotation as a Mechanism for Learning. Centre for Labor Market and Social Research, working paper.

McClelland, D. C., \& Burnham, D. H. (2003). Power is the Great Motivator. Harvard Business Review, 117-126.

Metin, M. C., Thomas, J., \& Miceli. (1998). On Job Rotation. Department of Economics Working Paper Series of University of Connecticut. Working paper, 25-27.

Ombogo, P. L. (2006). Strategy for Access to Water and Sanitation Services in Informal Settlements The Kissing Experience. Paper presented at the Africite conference Nairobi Kenya September.

Ortega, L. (1999). Planning and Focus on Form in L2 Oral Performance. Studies in Second Language Acquisition, 21, 109-148. http://dx.doi.org/10.1017/S0272263199001047

Parsons, T. (1951). The Social System. New York: The Free Press.

Plowman, N. (2010). Qualititative Research in Organizations and Management.

Ritzer, G. (1992). Sociological Theory. New York: McGraw-Hill.

Rodgers, R., \& Hunter, J. E. (1991). A Foundation of Good Management Practice in Government: Management by Objectives. Public Administration Review, 52(1), 27-39. http://dx.doi.org/10.2307/976543

Schermerhorn et al. (2004). Management: An Asia Pacific perspective (1st ed.). Australia: John Wiley \& Sons.

Schwandt, D. R. (1997). Exploring Dynamic Organizational Learning Processes: A Social Action Theory Perspective. In M. Kelleher (Ed.), Learning Organizations. European Consortium on Organizational Learning.

Senge, P. M. (1999). The Dance of Change. New York: Currency/Doubleday.

Shahin, R., \& Saravani, B. A. (2013). Investigating the Influence of Job Rotation on performance by Considering Skill Variation and Job Satisfaction of Bank Employees. Technical Gazette, 20(3), 473-478

Watson, D. (2007). Managing Civic and Community Engagement. Maidenhead: Open University Press.

Weichel, et al. (2010). Job rotation - Implications for Old and Impaired Assembly line Workers. Occupational Ergonomics, 9, 67-74.

Xie, J. L., \& Johns, G. J. (1995). Scope and Stres: Can Job Scobe Be Too High. The Academy of Management Journal, 38, 1288-1309. http://dx.doi.org/10.2307/256858

\section{Copyrights}

Copyright for this article is retained by the author(s), with first publication rights granted to the journal.

This is an open-access article distributed under the terms and conditions of the Creative Commons Attribution license (http://creativecommons.org/licenses/by/3.0/). 